\title{
Penerapan Principal Component Analysis dalam Penentuan Faktor Dominan Cuaca Terhadap Penyebaran Covid-19 di Surabaya Khusnia Nurul Khikmah ${ }^{1}$ \\ ${ }^{1}$ Departemen Matematika, Fakultas MIPA, Universitas Negeri Surabaya, Surabaya, 60231, Indonesia \\ * Corresponding author, email: khusnia.17030214054@mhs.unesa.ac.id
}

\begin{abstract}
Coronavirus disease 2019 (COVID-19) is an infectious disease caused by the acute respiratory syndrome coronavirus 2 (SARS-CoV-2) and the transmission can mediate human-to human by enviroment. According to Indonesian Meterological, Climatological, and Geophysical Agency found that weather and climate were supporting factors of COVID-19 outbreak so, research and analysis is carried out regarding the most factor were supporting the spread of COVID-19. In this study, using secondary data obtained from data reported by Indonesian Meterological, Climatological, and Geophysical Agency. According the aims of this study by using Principal Component Analysis (PCA) there are three principal components which represents the most factor were supporting the spread of COVID-19 they are temperature, humidity, and length of sunshine.
\end{abstract}

Keywords: Covid-19, Factor, Principal Component Analysis, Surabaya, Weather.

\begin{abstract}
Abstrak
Penyakit Coronavirus 2019 (COVID-19) merupakan penyakit menular yang disebabkan oleh sindrom pernapasan akut corona virus 2 (SARS-CoV-2) dan perantara penularannya yaitu antarmanusia dengan melelaui lingkungan. Menurut Badan Meteorologi, Klimatologi, dan Geofisika Indonesia menemukan bahwa cuaca dan iklim merupakan faktor pendukung wabah COVID-19 sehingga dilakukan penelitian dan analisis mengenai faktor yang paling mendukung penyebaran COVID-19. Dalam penelitian ini menggunakan data sekunder yang diperoleh dari data yang dilaporkan oleh Badan Meteoroologi, Klimatologi, dan Geofisika Indonesia. Berdasarkan tujuan dari penelitian ini dengan menggunakan Principal Component Analysis (PCA) terdapat tiga komponen utama yang mewakili faktor paling banyak mendukung penyebaran COVID-19 yaitu suhu, kelembaban, dan lama sinar matahari.
\end{abstract}

Kata Kunci: Covid-19, Cuaca, Faktor, Principal Component Analysis, Surabaya.

\section{Pendahuluan}

Coronavirus adalah keluarga besar virus yang menyebabkan penyakit pada manusia dan hewan. Pada Desember 2019 ditemukan virus corona jenis baru di Wuhan China, yang kemudian diberi nama Severe Acute Respiratory Syndrome Coronavirus 2 (SARSCoV-2) yang menyebabkan Coronavirus Disease-2019 [1]. COVID-19 dapat menyebar melalui tetesan kecil dari hidung atau mulut saat batuk atau bersin [1]. Infeksi COVID19 juga dapat menyebar jika seseorang menyentuh permukaan yang terinfeksi dan kemudian menyentuh mata, hidung, atau mulut [2].

Estimasi: Journal of Statistics and Its Application

e-ISSN: 2721-3803, p-ISSN: 2721-379X

http://journal.unhas.ac.id/index.php/ESTIMASI 
Masa inkubasi COVID-19 diperkirakan 14 hari, dengan sebagian besar kasus terjadi sekitar empat hingga lima hari setelah terpapar [3]. Menurut Kementerian Kesehatan RI, tidak ada batasan usia bagi orang yang dapat terinfeksi COVID-19 [1]. Centers for Disease and Prevention China melaporkan bahwa sekitar 44.500 kasus COVID-19 telah dikonfirmasi, dengan $87 \%$ berusia antara 30 dan 79 tahun [4]. COVID-19 menular dengan perantara manusia ke manusia melalui lingkungan [5]. Indonesia khususnya Surabaya memiliki iklim tropis dan daerah tropis juga cocok untuk penyebaran COVID-19 [6]. Berdasarkan hasil kajian Badan Meterologi, Klimatologi, dan Geofisika (BMKG) Indonesia ditemukan bahwa cuaca dan iklim merupakan faktor pendukung terjadinya wabah COVID-19 [7]. Jadi, masuk akal jika dilakukan penelitian dan analisis mengenai faktor yang paling mendukung penyebaran COVID-19.

Principal Component Analysis (PCA) merupakan salah satu teknik multivariate untuk menganalisis data [8]. Tujuan PCA adalah untuk mengekstrak informasi penting dari data dan mengaturnya ke variabel baru yang disebut komponen utama. PCA juga digunakan untuk meringkas data dengan jumlah variabel yang lebih kecil [9]. Dalam penelitian ini akan dilakukan perhitungan untuk mengetahui faktor dominan yang mendukung penyebaran COVID-19.

\section{Material dan Metode}

\subsection{Principal Component Analysis}

Principal Component Analysis (PCA) merupakan salah satu teknik multivariate untuk menganalisis data [8]. Tujuan PCA adalah untuk mengekstrak informasi penting dari data dan mengaturnya ke variabel baru yang disebut principal component (komponen utama). PCA juga digunakan untuk meringkas data dengan jumlah variabel yang lebih kecil [9].

Principal Component Analysis mempunyai beberapa fungsi, yaitu:

a. Mengidentifikasi variabel baru dari data multivariable.

b. Mereduksi jumlah variabel asli menjadi variabel independen tetapi tetap mempertahankan informasi dari data asli.

c. Mereduksi variabel asli yang memiliki informasi relatif sedikit dari data asli [10].

Misalkan $X=\left(X_{1}, X_{2}, \ldots, X_{p}\right)$ adalah vektor variabel asli dan ditransformasikan menjadi vektor variabel baru $K=\left(K_{1}, K_{2}, \ldots, K_{q}\right)$ dimana $q<p$, persamaan tersebut dapat ditulis dengan:

$$
K_{i}=b_{1 i} X_{1}+b_{2 i} X_{2}+b_{3 i} X_{3}+\cdots+b_{p i} X_{p}
$$

Dimana $b_{1 i}^{2}+b_{2 i}^{2}+b_{3 i}^{2}+\cdots+b_{p i}^{2}=1$.

Principal Component Analysis dari (1) dapat ditulis menjadi persamaan (2):

$$
\begin{aligned}
& K_{1}=b_{11} X_{1}+b_{21} X_{2}+b_{31} X_{3}+\cdots+b_{p 1} X_{p} \\
& K_{2}=b_{12} X_{1}+b_{22} X_{2}+b_{32} X_{3}+\cdots+b_{p 2} X_{p}
\end{aligned}
$$




$$
\begin{gathered}
\begin{array}{c}
\text { Penerapan Principal Component Analysis } . . \\
\text { Khusnia Nurul Khikmah }
\end{array} \\
K_{q}=b_{1 q} X_{1}+b_{2 q} X_{2}+b_{3 q} X_{3}+\cdots+b_{p q}
\end{gathered}
$$

Dimana:

$p=$ banyaknya variabel awal

$K_{i}=$ komponen ke- $i, i=1,2, \ldots, q$

$b_{p q}=$ pembebanan variabel $p$ ke- $q[8],[11]$.

\subsection{Matriks Masukan}

Dalam [11] matriks varians digunakan jika semua variabel satuan ukur adalah sama dan matriks korelasi digunakan bila semua variabel satuan ukur berbeda.

a. Matriks varians-kovarians

Pengukuran sebaran data disebut variance dan covariance adalah untuk mengetahui seberapa kuat hubungan antara dua variabel. Nilai variance-covariance dapat diperoleh dengan mengikuti persamaan:

$$
\begin{gathered}
S_{j j}=\frac{\sum_{j=1}^{p}\left(X_{i j}-\overline{X_{J}}\right)^{2}}{(p-1)} \\
S_{i j}=\frac{\sum_{j=1}^{p}\left(X_{i j}-\overline{X_{l}}\right)\left(x_{i j}-\overline{X_{J}}\right)}{(p-1)}
\end{gathered}
$$

Matriks varians-kovarian baru dapat ditulis dengan persamaan berikut:

Dimana:

$$
S_{p \times p}=\left[\begin{array}{cccc}
S_{11} & S_{12} & \cdots & S_{1 p} \\
S_{21} & S_{22} & \cdots & S_{2 p} \\
\vdots & \vdots & \ddots & \vdots \\
S_{p 1} & S_{p 2} & \cdots & S_{p p}
\end{array}\right]
$$

$S_{j j}=$ nilai varians

$S_{i j}=$ nilai kovarians

$S=$ matriks varian-kovarian [11], [12].

b. Matriks Korelasi

Matriks dengan elemen diagonal utama berjumlah 1 disebut matriks simetris.

Korelasi $(r)$ bertujuan untuk mengukur kekuatan hubungan linier antara dua variabel. Nilai korelasi dapat dilambangkan dengan persamaan:

$$
r=\frac{s_{i j}}{\sqrt{S_{i i} S_{j j}}}=\frac{\sum_{j=1}^{p}\left(X_{i j}-\overline{X_{l}}\right)\left(X_{i j}-\overline{X_{J}}\right)}{\sqrt{\sum_{j=1}^{p}\left(X_{i j}-\overline{X_{l}}\right)^{2} \sum_{j=1}^{p}\left(X_{i j}-\overline{X_{J}}\right)^{2}}}
$$

Matriks korelasi dapat ditulis dengan mengikuti persamaan berikut:

Dimana:

$$
R_{p \times p}=\left[\begin{array}{cccc}
1 & r_{12} & \cdots & r_{1 p} \\
r_{21} & 1 & \cdots & r_{2 p} \\
\vdots & \vdots & \ddots & \vdots \\
r_{p 1} & r_{p 2} & \cdots & 1
\end{array}\right]
$$

$r=$ variabel koefisien korelasi dari $X_{i}$ dan $X_{j}$

$R=$ matriks korelasi [11], [12]. 


\subsection{Koefisien Pembobot Komponen Utama}

Penafsiran variabel komposit yang dihasilkan adalah tujuan dari pembebanan principal component (komponen utama). Dari persamaan (2.1) untuk menentukan vektor koefisien $b_{i}=b_{1 i}, b_{2 i}, b_{3 i}, \ldots, b_{p i}$ dapat diselesaikan dengan menggunakan fungsi lagrange:

$$
L=b_{i}^{T} X^{T} X b_{i}-\lambda\left(b_{i}^{T} b_{i}-1\right)
$$

dengan syarat $b_{i}^{T} b_{i}=1$ untuk $b_{i}^{T} X^{T} X b_{i}$ mencapai nilai maksimum.

Jika $L$ diturunkan oleh vektor $b$ dan sama dengan nol, maka:

$$
\begin{aligned}
\frac{\partial L}{\partial b}=2 b_{i} X^{T} X-2 \lambda b_{i} & =0 \\
2\left(X^{T} X-\lambda I\right) b_{i} & =0 \\
\left(X^{T} X-\lambda I\right) b_{i} & =0
\end{aligned}
$$

Hasil dari $(X-\lambda I) b_{i}=0$ adalah non-trivial dan hanya ada satu solusi:

$$
\left|X^{T} X-\lambda I\right|=0
$$

Persamaan (10) akan dihasilkan akar karakteristik $\lambda_{i}$ dimana $\lambda_{1}>\lambda_{2}>\lambda_{3}>\cdots>\lambda_{q}>$ 0 dan selanjutnya setiap akar karakteristik $\lambda_{i}$ akan ditentukan $b_{i}$ [11].

\subsection{Penentuan Principal Component}

Untuk menentukan principal component (komponen utama) dapat mengikuti kriteria sebagai berikut:

a. Proporsi Kumulatif Varians Total

Proporsi kumulatif dari varian total dapat ditentukan dengan memilih $k$ principal component (komponen utama) sebagai kontribusi terbesar dari varians data dan mempunyai proporsi kumulatif lebih dari $75 \%$.

$$
\frac{\sum_{j=1}^{k} \lambda_{j}}{\sum_{j=1}^{p} \lambda_{j}}>0.75
$$

Dimana:

$\sum_{j=1}^{k} \lambda_{j}=$ varians komponen utama ke-j, $j=1,2, \ldots, k$

$\sum_{j=1}^{p} \lambda_{j}=$ varians total, $j=1,2, \ldots, p$.

b. Akar Karakteristik

Komponen yang dipilih memiliki karakteristik root lebih besar dari satu [11].

\subsection{Metode Penelitian}

Analisis dalam penelitian dilakukan dengan cara:

a. Studi Literatur

b. Persiapan data

Data dalam penelitian ini menggunakan sekunder dari situs resmi Badan Meteorologi, Klimatologi, dan Geofisika Indonesia. Data diambil dari tanggal 1 April 2020 sampai dengan 14 September 2020

c. Menentukan variabel penelitian

Variabel dalam penelitian ini adalah: 
1. $X_{1}=$ suhu

2. $X_{2}=$ kelembapan

3. $X_{3}=$ lama penyinar matahari

4. $X_{4}=$ kecepatan angin

d. Melakukan Principal Component Analysis dengan:

1. Menentukan matriks korelasi;

2. Menentukan akar karakteristik dan vektor karakteristik;

3. Tentukan banyaknya principal component (komponen utama);

4. Menentukan nilai komponen pembobot.

e. Ploting PCA3D.

\section{Hasil dan Diskusi}

\subsection{Principal Component Analysis}

\subsubsection{Matriks Korelasi}

Korelasi digunakan untuk mengukur kekuatan hubungan linier dua variable atau lebih. Misalkan $R$ adalah matriks korelasi dari faktor cuaca dan iklim yang akan digunakan untuk mendapatkan koefisien pembobot komponen utama maka dengan bantuan software Rstudio diperoleh:

$$
R=\left[\begin{array}{cccc}
1,0000000 & -0,0020629 & 0,112718 & 0,137543 \\
-0,0020629 & 1,0000000 & 0,060553 & -0,460531 \\
0,1127182 & 0,0605527 & 1,000000 & -0,026185 \\
0,1375433 & -0,4605311 & -0,026185 & 1,00000
\end{array}\right]
$$

Koefisien pembobot komponen utama bisa didapatkan dengan terlebih dahulu melakukan Uji Bartlett untuk menganalisis bahwa matriks korelasi $R$ bukan matriks identitas dengan $H_{0}$ : matriks korelasi = matriks identitas dan $H_{1}$ : matriks korelasi bukan matriks identitas. Hasil Uji Bartlett dengan Rstudio yang didapat bahwa p-value yang diperoleh yaitu mendekati 0 yaitu 0,0000000335 sehingga menolak hipotesis null $\left(H_{0}\right)$ artinya matriks korelasinya bukan matriks identitas. Jadi, analisis faktor cuaca dan iklim dengan menggunakan Principal Component Analysis dapat dilanjutkan karena matriks korelasinya bukan matriks identitas.

\subsubsection{Koefisien Pembobot dan Jumlah Principal Component}

Nilai koefisien pembobot diperoleh melalui matriks korelasi untuk mengetahui masing-masing kontribusi variabel ke masing-masing komponen. Sebelum menemukan nilai pembobot nilai eigen value dari matriks korelasi terlebih dahulu dicari. Misalkan $L$ adalah nilai eigen dari matriks korelasi, nilai $L$ adalah:

$$
L=1,484141,123020,872920,51993
$$

Sedangkan nilai pembobotnya yaitu:

$$
\begin{array}{ccccc} 
& \text { Suhu } & \text { Kelembapan } & \text { lama penyinaran matahari } & \text { kecepatan angin4 } \\
\text { Suhu } & 0,2245 & 0,7353 & 0,6230 & -1,44 \mathrm{e}-01 \\
\text { Kelembapan } & -0,8294 & 0,1638 & 0,2153 & 4,89 \mathrm{e}-01 \\
\text { lama penyinaran matahari } & -0,0979 & 0,7436 & -0,6614 & 1,22 \mathrm{e}-06 \\
\text { kecepatan angin } & 0,8580 & 0,0507 & -0,0303 & 5,10 \mathrm{e}-01
\end{array}
$$


Dari pembobot, kita dapat mengetahui principal component (komponen utama) yang memberikan dampak besar ke semua variabel yaitu suhu, kelembapan, dan lama penyinaran matahari:

$\begin{array}{ccc}\text { Suhu } & \text { Kelembapan } & \text { lama penyinaran matahari } \\ 0,2245 & 0,7353 & 0,6230 \\ -0,8294 & 0,1638 & 0,2153 \\ -0,0979 & 0,7436 & -0,6614 \\ 0,8580 & 0,0507 & -0,0303\end{array}$

Selain dari melihat nilai yang dihasilkan dari pembobot komponen pemberi dampak terbesar ke semua variabel juga bisa dilihat dari scree plot seperti di bawah yaitu dari component number yang berada di atas limit ada dua yaitu component number 1,2 , dan 3.

\subsubsection{Nilai dari Pembobot Komponen}

Misalkan $l$ adalah nilai pembobot (loading) komponen utama dari hasil Principal component analysis. nilai $l$ adalah:

$$
l=1,481,120,870,52
$$

dengan proporsi kumulatif ragam komponen, misalkan $C V$ :

$$
C V=0,370,650,871,00
$$

Total kumulatif ragam dari principal component (komponen utama) yaitu suhu, kelembapan, dan lama penyinaran matahari adalah sebesar $87 \%$, artinya sebesar $87 \%$ dari data terakomodasi pada ketiga komponen tersebut dan memenuhi persamaan (11).

\subsection{Grafik PCA3D}

Principal Component Analysis dengan tiga faktor dominan menghasilkan grafik PCA3D seperti Gambar 2. Berdasarkan hasil Principal Component Analysis diperoleh bahwa suhu, kelembapan, dan lama penyinaran matahari adalah faktor dominan cuaca yang berpengaruh besar terhadap penyebaran COVID-19 di Surabaya oleh karena itu, hasil analisis ini dapat digunakan sebagai bahan pertimbangan dalam membuat keputusan terhadap persebaran COVID-19 berdasarkan kondisi cuaca di Surabaya.

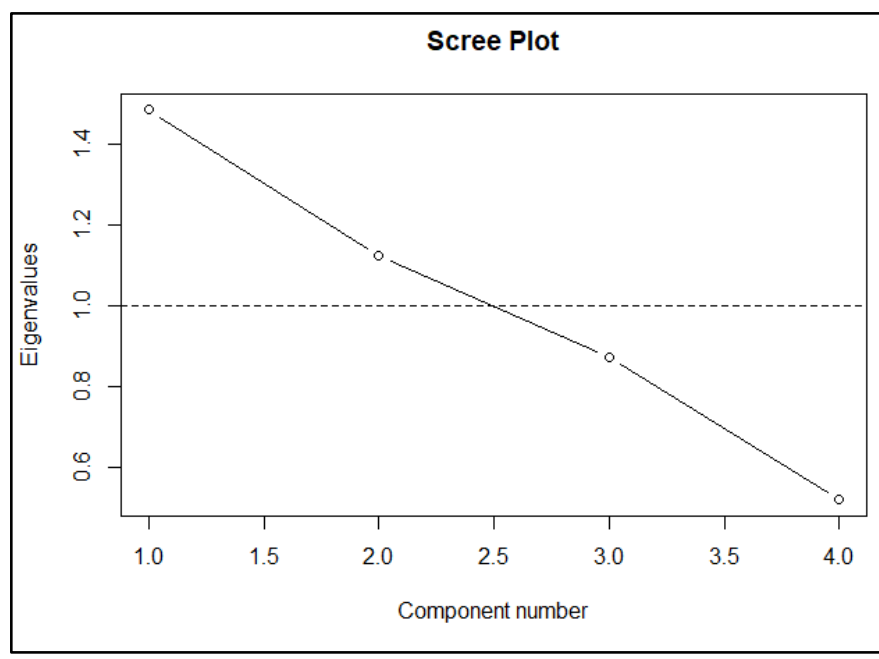

Gambar 1. Scree plot Principal Component Analysis 


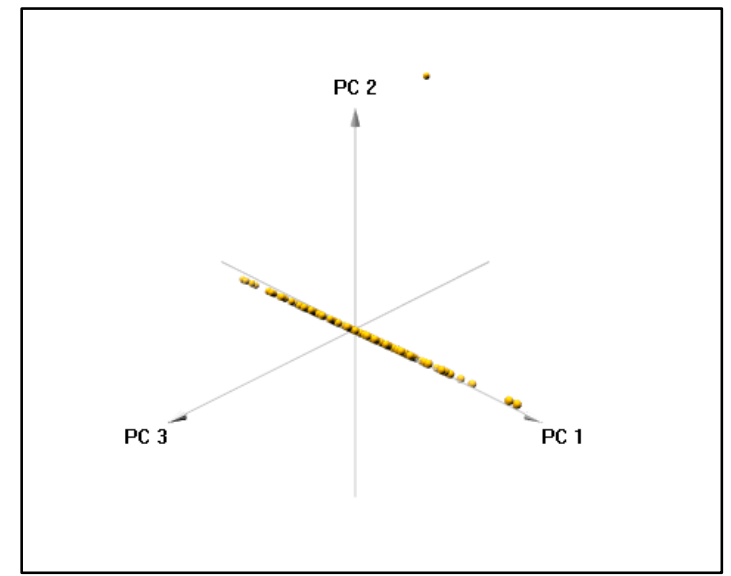

Gambar 2. Grafik pca3d komponen utama

\section{Kesimpulan}

Berdasarkan Principal Component Analysis, kesimpulan dari penelitian ini adalah:

1. Hasil Principal Component Analysis dipilih tiga principal component (komponen utama) yang memberikan informasi paling banyak (varians) dari data.

2. Tiga komponen yang paling bervariasi pada data adalah suhu, kelembaban dan lama sinar matahari.

\section{Daftar Pustaka}

[1] K. K. R. Indonesia. https://www.kemkes.go.id/folder/view/full-content/structurefaq.html (accessed Jul. 26, 2020).

[2] N. Van Doremalen et al. Aerosol and surface stability of SARS-CoV-2 as compared with SARS-CoV-1. N. Engl. J. Med., 382 (16) : 1564-1567, 2020.

[3] S. Poudel, Knowledge and Attitudes of Adults in Jhapa District Towards Coronavirus Disease 2019 (COVID-19), 2020.

[4] Z. Wu \& J. M. McGoogan, Characteristics of and important lessons from the coronavirus disease 2019 (COVID-19) outbreak in China: summary of a report of 72314 cases from the Chinese Center for Disease Control and Prevention. Jama, 323 (13) : 1239-1242, 2020.

[5] M. M. Sajadi, P. Habibzadeh, A. Vintzileos, S. Shokouhi, F. Miralles-Wilhelm \& A. Amoroso. "Temperature and latitude analysis to predict potential spread and seasonality for COVID-19," Available SSRN 3550308, 2020.

[6] M. B. Araujo \& B. Naimi. Spread of SARS-CoV-2 Coronavirus likely to be constrained by climate. medRxiv, 2020.

[7] M. Wareza. BMKG:Suhu Dan Kelembapan Tak Ideal Bagi Penyebaran Covid-19. [Online]. Available: https://www.cnbcindonesia.com/news/20200404143119-4149777/bmkg-suhu-kelembapan-ri-tak-ideal-bagi-penyebaran-covid-19, 2020.

[8] H. Abdi \& L. J. Williams. Principal component analysis. Wiley Interdiscip. Rev. Comput. Stat., 2 (4) : 433-459, 2010. 


\section{Penerapan Principal Component Analysis ... Khusnia Nurul Khikmah}

[9] I. T. Jolliffe. Principal component analysis. Technometrics, 45 (3) : 276, 2003.

[10] F. Solimun, AAR \& Nurjannah. Multivar. Stat. Method Struct. Equ. Model. Based WarpPLS. 2017.

[11] S. Astutik. Analisis Multivariat: Teori dan Aplikasinya dengan SAS. Universitas Brawijaya Press, 2018.

[12] R. A. Johnson \& D. W. Wichern, Applied multivariate statistical analysis, 5 (8). Prentice hall Upper Saddle River, NJ, 2002. 